\title{
Springtime Meteorology of Damauli Valley, Nepal: Implications for Climatic Comfort and Environmental Hygiene
}

\author{
Sangeeta Maharjan \\ National Atmospheric Resource and Environmental Research Laboratory (NARERL) \\ Central Department of Physics, Tribhuvan University, Kirtipur, Kathmandu, Nepal. \\ E-mail: sangeetamaharjan@gmail.com
}

\begin{abstract}
Springtime spatial and temporal distributions of temperature and humidity over the Damauli valley have been numerically assessed to examine thermal comfort and environmental hygiene. The study reveals that the near surface temperature over valley may remain at 24, 34 and $27 \mathrm{C}$ during the morning, afternoon and in the evening, respectively, and the relative humidity may remain in between 25 to $30 \%$ during the spring season. The high temperature and low humidity can significantly degrade environmental hygiene over the valley.
\end{abstract}

Keywords: Atmospheric modeling, thermal comfort, environmental hygiene, Damauli valley.

\section{INTRODUCTION}

Although mountain meteorology has been an active area of research for many years and also occupies large volume of literature, the meteorology of the high mountainous region of Himalayas has not been extensively studied. Only a few of studies have been reported from this region, (Regmi et. al. 2003) studied the late wintertime local flows over the Kathmandu valley; Ramanathan and Srinivasan (1998) studied the summer time air flow in the Kashmir valley of India, Zängl et al. (2001) studied the diurnal wind in the Himalayan Kaligandaki valley of western Nepal, Ohata et al. (1981) observed the mountain-valley wind system in the Khumbu Himal in the eastern Nepal. This shows that there is much to know about the characteristic meteorological flows over Nepal Himalaya, which can have profound implications in understanding prevailing weather and climate of the whole Asian sub-continent.

As part of the ongoing effort to characterize the springtime meteorological flow system over the mid hills of Nepal Himalaya, present study has been conducted over the Damauli valley, a narrow and deep riverbed valley, located in the western development region of Nepal. The valley is typically situated on the confluence of two major rivers, namely, Madi and Seti Rivers and is in proximity to the vast tropical Gangetic Plain of India in the south and the great Himalayan Chain in the north. The valley floor is situated at an average elevation of 650 meters above the mean sea level (AMSL) and accommodates Vyas Municipility with 36000 residents. Mountains and hills rising up to 1640 meters surround the valley. Fig. 1 may reflect the topographic complexities of the valley and its surrounding areas.

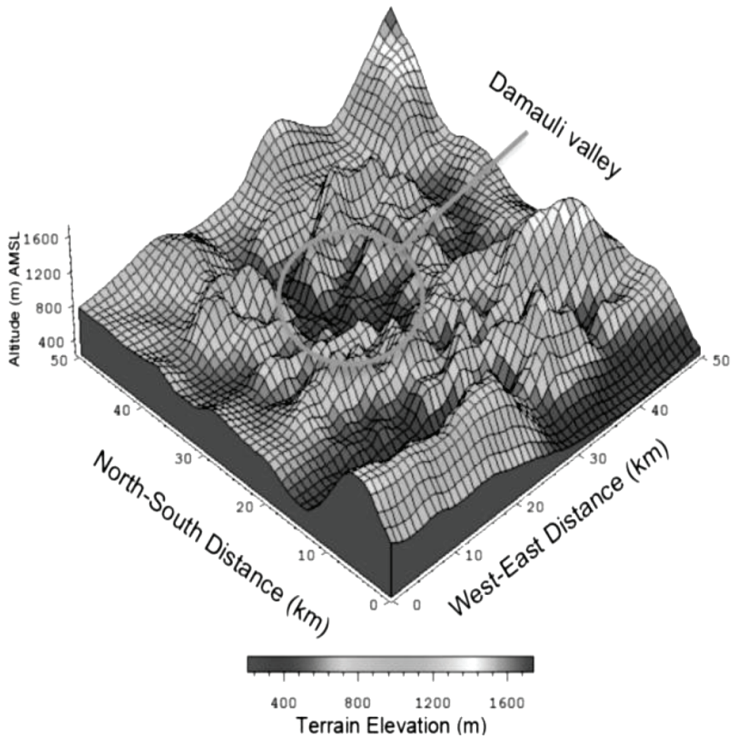

Fig. 1. Three-Dimensional topographic view of Damauli Valley and its surroundings. The circle encloses the valley.

Several case studies and research on epidemiology have shown that dehydration, cell membrane contraction, nose tissue inflammations or influenza and fever are closely associated with prevailing temperature and humidity. The prevalence of low humidity is also believed to favor the growth of allergies and respiratory diseases along with the existence of diseases like fungi (e.g., Aspergillusfumigatus, protozoa, house dust mite, bacteria (e.g., Streptococcus, Legionella) and virus (e.g., common cold, flu) (Baughman \& Arens, 1996; Ikeda et al. 2003; Sookchaiya et al. 2010). 
In this paper we will present the spatial and temporal distributions of the temperature and humidity during the spring season as revealed by the numerical simulation since prevailing temperature and humidity are considered to be the most relevant parameters to assess climatic comfort and environmental hygiene of an area of interest.

\section{MATERIALS AND METHODS}

The third generation Weather Research and Forecasting WRF Modeling System (Skamarock et al. 2008) with core ARW has been applied to compute and to map the spatial-temporal distribution of surface temperature, vertical distribution of temperature and humidity over an area of $51 \mathrm{~km} \times 51 \mathrm{~km}$ that covers the Damauli valley and its immediate surrounding areas. It is a fully compressible and non-hydrostatic model with a run-time hydrostatic option.

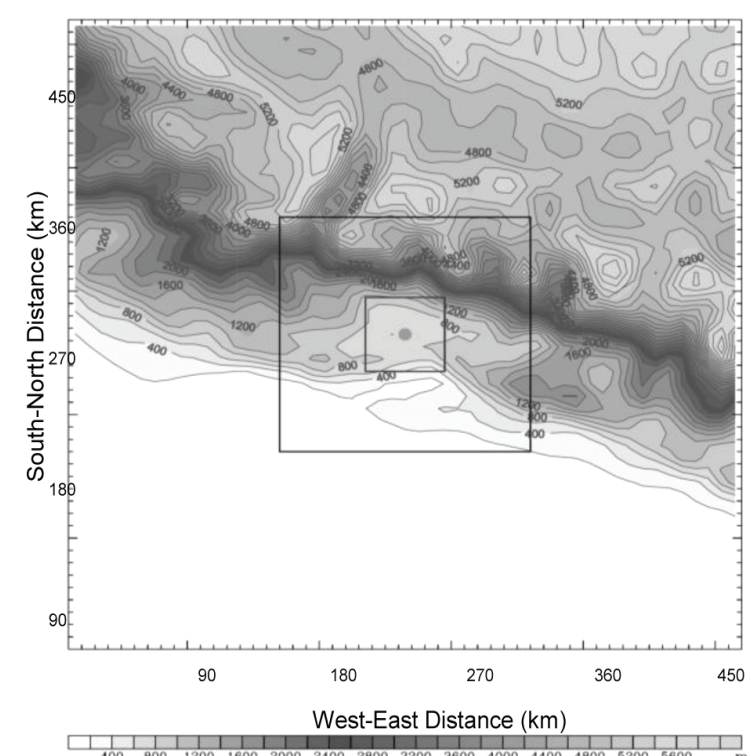

Fig. 2. Domain configurations adopted for the numerical simulation.

The model utilizes a terrain-following hydrostatic pressure coordinate system, Arakawa C-grid staggering and Runge-Kutta 2nd and 3rd order time integration schemes, and 2 nd to 6 th order advection schemes in both the horizontal and vertical, thus, making highly suitable to perform simulation over a highly complex terrain. A triply nested two-way interacting mesh of $51 \times 51 \times 34$ grid points with horizontal grid sizes 9, 3, $1 \mathrm{~km}$ for coarse, fine, and finest domains, respectively, was adopted for this calculation (Fig. 2 for domain configuration and area coverage). The physics options/schemes used in this calculation include WSM 3-class simple ice, Kain-Fritsch (for coarse domain only), Unified NOAH land-surface,
YSU Planetary Boundary Layer, RRTM long wave, and Dhudhia short wave etc. The model was initialized with horizontal resolution 6 hourly meteorological data from National Centers for Environmental Prediction (NCEP) and the 24 categories land use and 30 second terrain elevation data by United States Geological Survey (USGS). The WRF model is initialized at 0000 UTC of a given day and is run for 48 simulated hours, storing the output every hour. The first day of the simulation has been discarded as a spin up of the model, and the values for the following 24 hours have been retained as the simulation for that day. After series of such simulations, we considered the April $2^{\text {nd }}$ as a representative day to describe the environment comfort over Damauli valley during the hot season.

\section{RESULTS}

During a weeklong simulation over the Damauli valley, almost the same pattern in the spatial and temporal distribution of temperature and humidity were predicted although minor day-to-day differences were apparent in the higher levels such as patches of clouds or higher humidity pocket areas. Thus, it appears reasonable to consider one of the simulation days as representative day to describe the general tendency of diurnal variation and spatial distribution of temperature and humidity over the valley.

\section{Spatial distribution of temperature}

The near surface temperature of the Damauli valley and its immediate surrounding areas appear to be extremely warm throughout the day. Even in the midnight, the central area of the valley appears to possess temperature of about $30 \mathrm{C}$ whereas the temperature over the outskirts appears to be $2^{\circ} \mathrm{C}$ less in comparison to the central area of the valley (Fig. 3a) and the temperature of about $27^{\circ} \mathrm{C}$ prevails over the adjacent valleys. However, over the mountaintops holds a relatively cooler environment at about $21^{\circ} \mathrm{C}$ and a chunk of areas in the south-southwest possesses $32^{\circ} \mathrm{C}$ during the same period. As the morning progresses, the earth cools down slowly and by 0645 local standard time (LST) the temperature over Damauli valley drops down to $24^{\circ} \mathrm{C}$ and the surrounding areas also show drop in its ambient temperature to some extent (Fig. 3b). With the increasing solar insolation after sunrise, the surface over the valley heats up rapidly and by 0945 LST in the morning (Fig. 3c) the temperature starts peaking up. Several square kilometer areas that lie within the 600 meters terrain contour show relatively higher temperature and over the Damauli bazaar there prevails about $29^{\circ} \mathrm{C}$ but over the southeastern part the temperature appears to be around $32 \mathrm{C}$. 

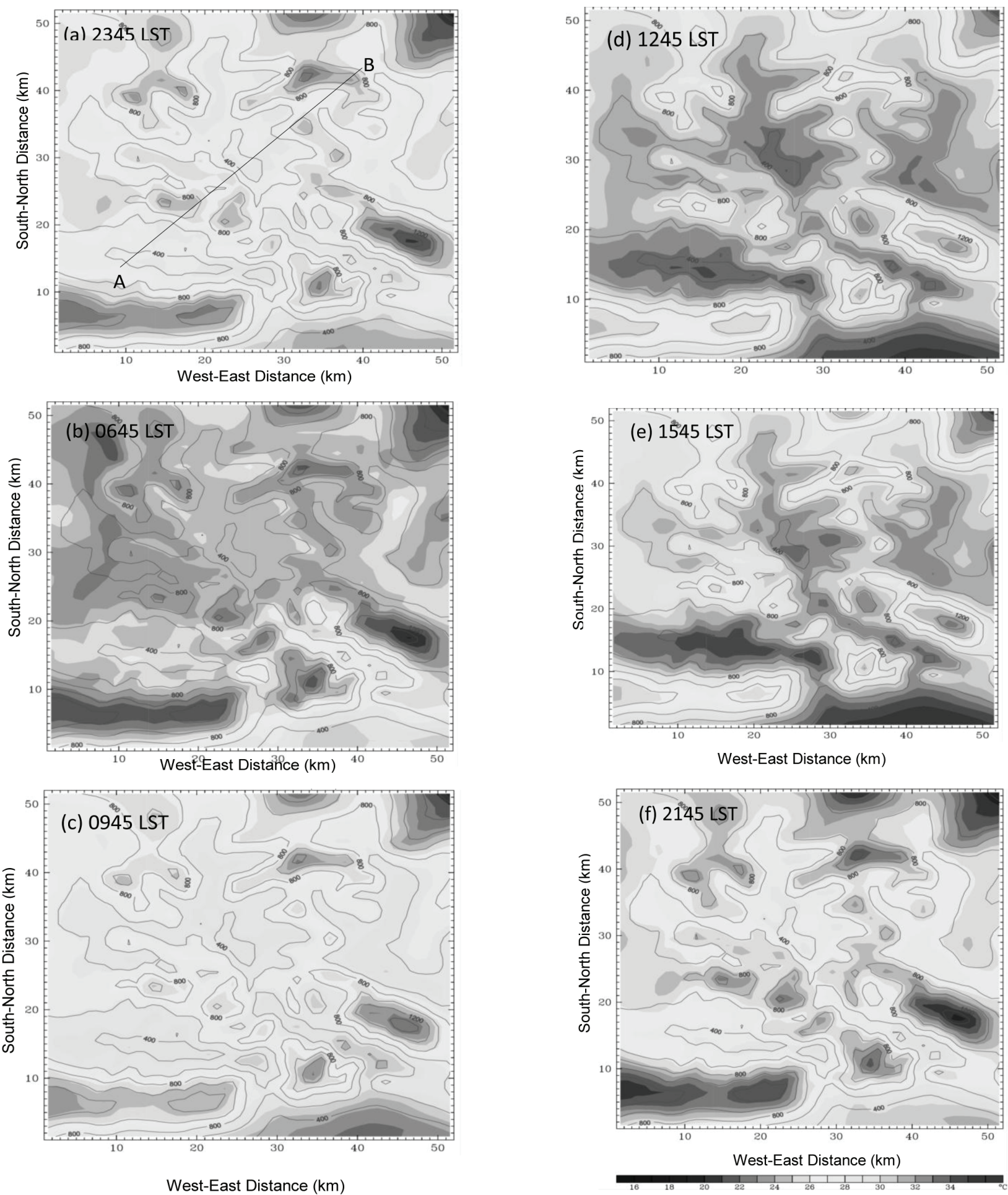

Temperature $\left({ }^{\circ} \mathrm{C}\right)$

Fig. 3: Spatial and temporal distribution of near surface temperature over Damauli valley.

As the noontime approaches, the temperature over the low-land enclosed by terrain contour of 800 meters high reaches to about $34 \mathrm{C}$. Such a higher temperature may prevail up to 1545 LST (Fig 2e). In the late afternoon and, particularly, after sunset, the ambient temperature gradually decreases and returns to the same situation described earlier for night and morning times. 


\section{Vertical variation of temperature}

Fig. 4 shows the vertical distribution of ambient temperature over the Damauli area along the line $\mathrm{A}-\mathrm{B}$ (Fig. 3a for orientation of the line $\mathrm{A}-\mathrm{B}$ ). During morning time, Damauli valley possesses uniform temperature of about $24^{\circ} \mathrm{C}$ up to 500 meters depth and then it decreases upwards. The layer of the atmosphere just above the surrounding mountaintops possesses temperature of about a degree less and the temperature of the layer of the atmosphere in between $3.5 \mathrm{~km}$ to about $4.5 \mathrm{~km}$ height above the mean sea level appears to be uniform at about $0 \mathrm{C}$. The temperature of the atmosphere aloft this layer further decreases and may reach up to $-12 \mathrm{C}$. As the morning progresses, rapid changes in the temperature profile is seen in the immediate atmosphere over the Damauli valley up to the height of $1 \mathrm{~km}$ above the ground leading to the formation of thermal internal boundary layers with significant temperature gradients (Fig. 4b). However, no significant change is seen above this layer.
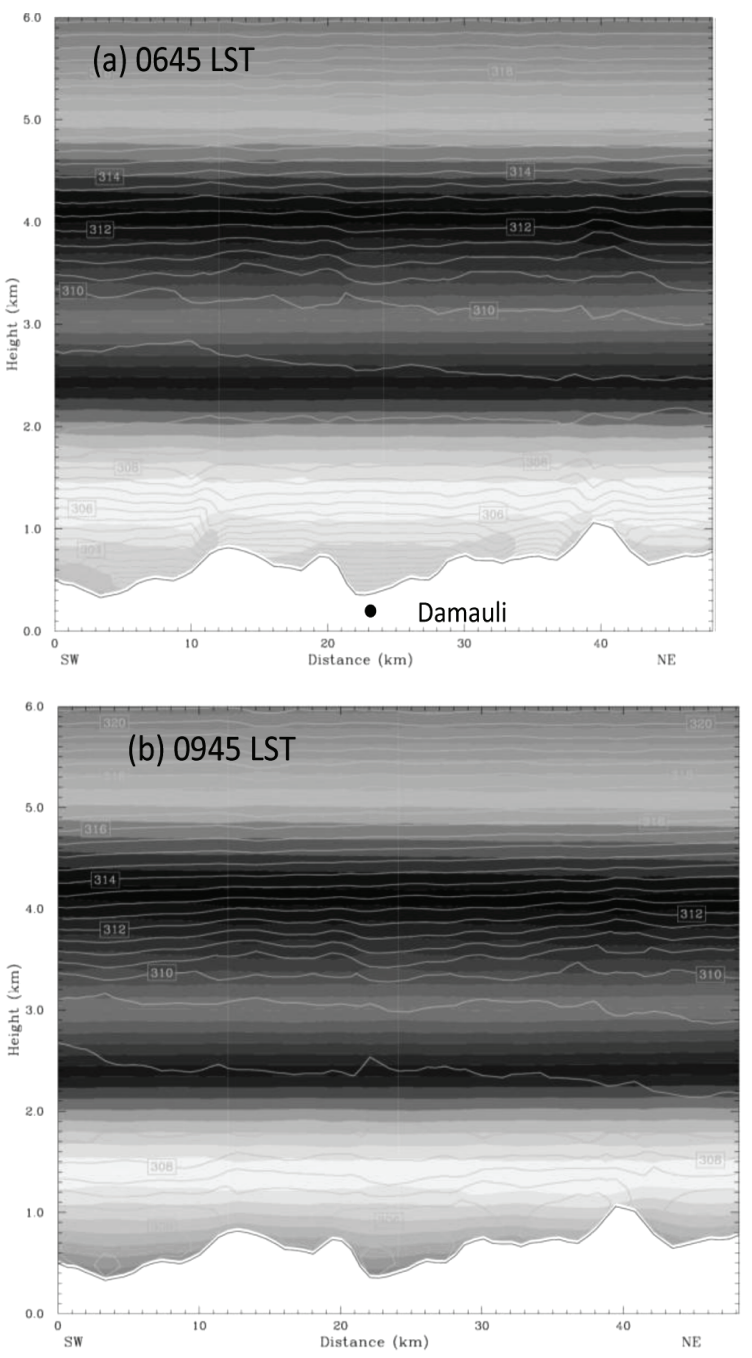
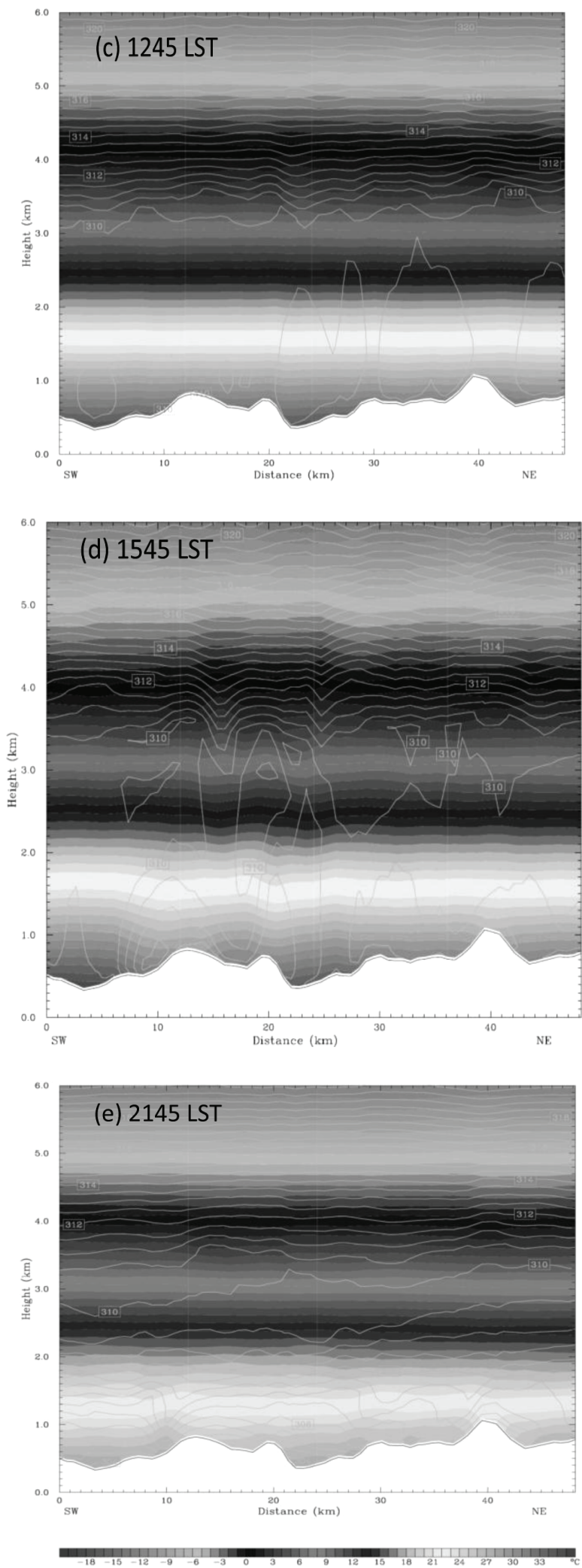

Fig. 4. Vertical profile of temperature fields along the cross-section AB passing through Damauli valley. 
The afternoon time is marked with sharp rise in temperature up to $1 \mathrm{~km}$ height above the ground. The temperature of the layer of the atmosphere below 300 meters may reach up to $31^{\circ} \mathrm{C}$ on the average and close to the surface it may reach around $34^{\circ} \mathrm{C}$ by this time (Fig. $4 \mathrm{c})$. This temperature profile remains fairly constant till late afternoon. In the dusk, the ambient temperature over the valley starts to decrease and gradually returns to the situation described earlier for night and morning. The diurnal variation of temperature profile over the Damauli valley shows a remarkable periodicity during the simulation days and may reflect the same for the spring season.

\section{Vertical profile of relative humidity}

In this sub-section, we will discuss the diurnal variation of vertical profile of relative humidity over the Damauli valley considering the same cross-section used for the description of the temperature in the previous sub-section. As can be seen in Fig. 5a, the relative humidity over the Damauli valley on the average may remain at about $27 \%$ up to $1 \mathrm{~km}$ height above the ground. As we move to upper levels, relative humidity appears to increase gradually increases reaching up to $75 \%$ in between $4 \mathrm{~km}$ to $6 \mathrm{~km}$ above the mean sea level. A small parcel of air at about $5 \mathrm{~km}$ high in the southwest appears to posses the relative humidity of about $85 \%$ (Fig. 5a).

The vertical distribution of relative humidity at lower levels appears more or less the same during night and early morning period but around $4 \mathrm{~km}$ above the mean sea level, irregular patches of relatively humid air masses appear shifting from southwest to northeast direction. The movement of relatively higher humid air masses is followed by decrease in relative humidity aloft (see Figs. 5a-b). The relative humidity over the valley may vary in between 25 to $30 \%$ up to the height of $1 \mathrm{~km}$ above the ground in between early and late mornings. Close to noontime, it attains a low but uniform distribution i.e, $25 \%$ up to $1.4 \mathrm{~km}$ above mean sea level.

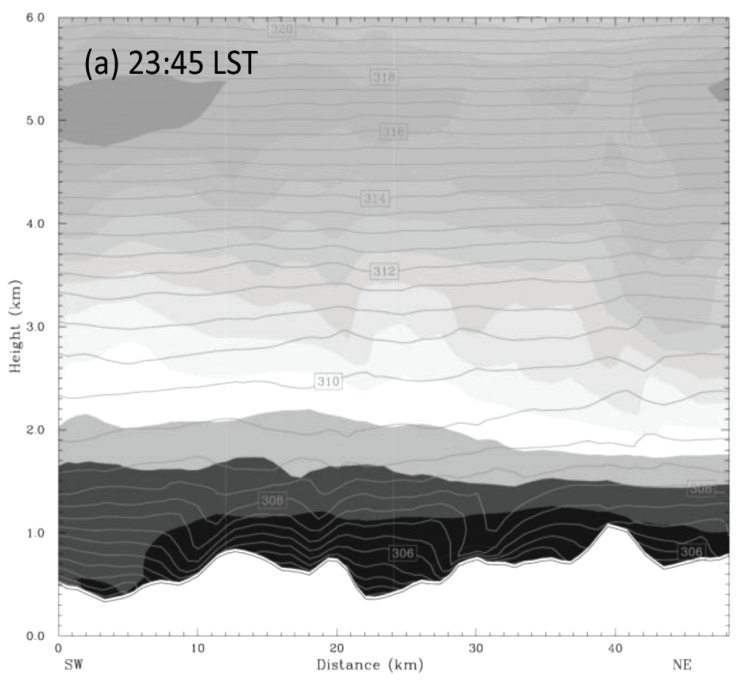

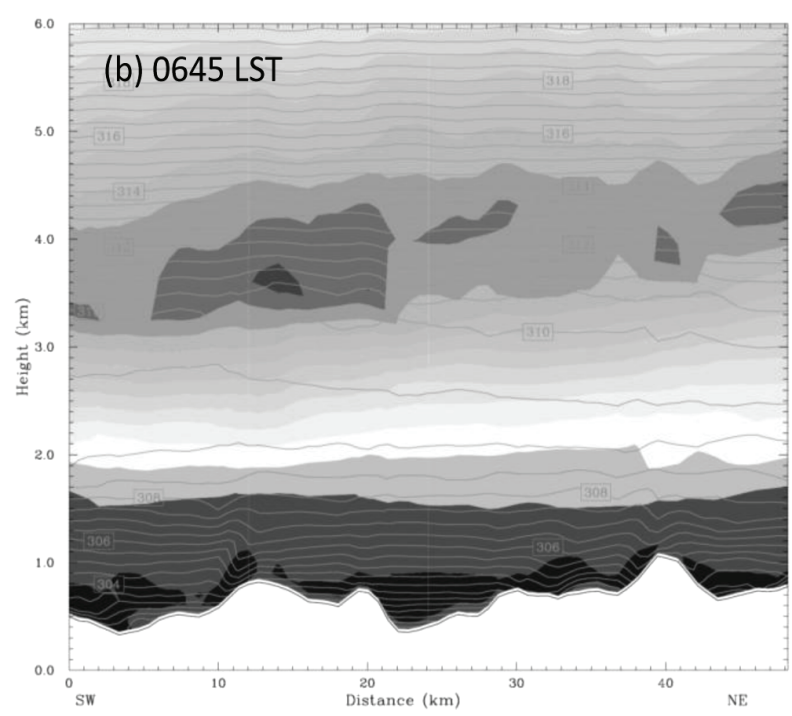
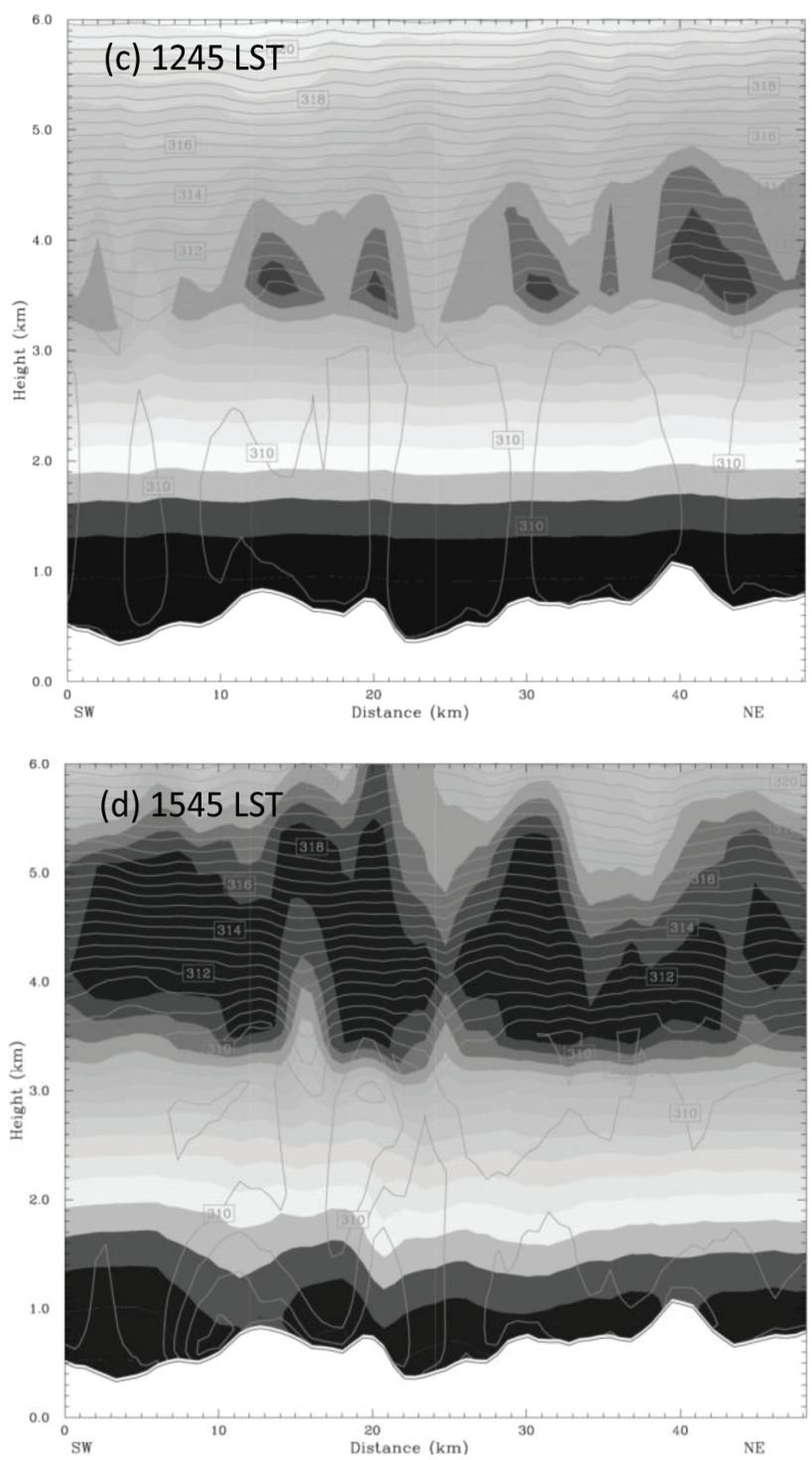


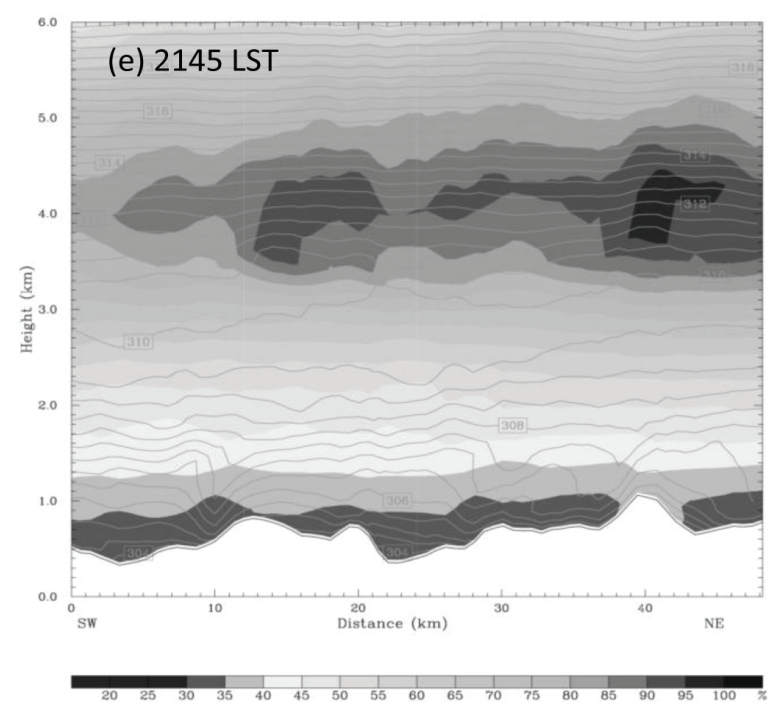

Fig. 5. Southwest-Northeast vertical cross-sectional profile of relative humidity over the Damauli valley (see the line $A-B$ in Fig. 3a for orientation).

In the afternoon, there is significant increase in relative humidity in the upper layer of the atmosphere but the immediate atmosphere over the valley up to surrounding mountaintops and just above it retain more or less the same low humidity (Fig. 5d). During the late afternoon (Fig. 5d) the layer of the atmosphere in between 3.5 to $5.5 \mathrm{~km}$ above the mean sea level appears to possess $100 \%$ relative humidity. This suggests that clouds might have developed in that layer as the surface temperature over the Damauli valley appears relatively cool compared to other times (see Figs. 3d-e).

Like the diurnal variation of temperature, the near surface relative humidity over the Damauli valley also shows the diurnal periodicity and there is little day-to-day variation during the simulation period. This may imply that during the spring season, the relative humidity over the Damauli valley remains very low.

\section{CONCLUSIONS}

The numerical simulation of meteorological flows over the Damauli valley reveals that the near surface temperature over valley may remain at $24^{\circ} \mathrm{C}, 34^{\circ} \mathrm{C}$ and $27^{\circ} \mathrm{C}$ during the morning, afternoon and in the evening, respectively, and the relative humidity over the valley may remain in between 25 to $30 \%$ during the spring season. Similar, scouting like study over the Kathmandu valley shows the relative humidity of about $55 \%$ and the temperature of about $22^{\circ} \mathrm{C}$ during the spring season (Maharjan \& Regmi, 2014). Thus, from the prospect of ambient temperature and humidity, it can be said that the prevailing springtime climate over the Damauli valley is not comfortable and hygienic in consistent with the general people's perception and experiences. The climate of the valley might have been strongly associated with dehydration, cell membrane contraction, nose tissue inflammations or influenza, fever, eye irritation and allergies. Time series epidemiological studies are necessary for exact evaluation of the association of the prevailing climate and the health outcomes of the people living in the valley.

\section{ACKNOWLEDGEMENTS}

This research was partially supported by the University Grant Commission, Nepal under its Institutional Grant Research Project. Also, I am thankful to Dr. Ram P. Regmi for his generous support to conduct this study.

\section{REFERENCES}

Baughman, A. V. and Arens, E.A. 1996. Indoor humidity and human health - part I: literature review of health effects of humidity-influenced indoor pollutants, ASHRAE Transactions 102 (1996) 193-211.[8] E.A. Arens, A.V. Baughman, Indoor

Ikeda, K., Ibamoto T et al. 2003. Experimantal Studies on Activities of the Virus in Low Humidity Indoor Environment, Annual Meeting of SHASE, pp.19011904

Kitada, T. and Regmi, R. P. 2003. Air pollutants distribution and their dynamics over the Kathmandu valley, Nepal: As revealed with numerical simulation. J. Appl. Meteo, 42: 1770-1789.

Maharjan, S. and Regmi, R. P. 2014. Grid Based Temperature and Relative Humidity Dustrubution Map of the Kathmandu Valley. Journal of Institute of Science and Technology 19(1): 7-13.

Ohata, T., Higuchi, K. and K. Ikegami, K. 1981. Mountain-valley wind system in the Khumbu himal, east Nepal. J. Meteor. Soc. Japan 59:753-762.

Ramanathan, N., and Srinvasan K. 1998: Simulation of airflow in Kashmir valley for a summer day. J. Appl. Meteor. 37: 497-508.

Regmi, R.P., Kitada, T. and Kurata, G. 2003. Numerical simulation of late wintertime local flows in the Kathmandu valley, Nepal: Implication for air pollution transport. J. Appl. Meteo. 42: 389-403.

Skamarock, W. C., et al. 2008. A description of the advanced research wrf version 3. Tech. Rep. NCAR/TN-475+STR, Mesoscale and Microscale Meteorology Division, National Center for Atmospheric Research, Boulder, Colorado, USA, $113 \mathrm{pp}$.

Sookchaiya, T., et al. 2010: Assessment of the thermal environment effects on human comfort and health for the development of novel air conditioning system in tropical regions. Energy and Building, 42 :16921702

Zängl, G., Egger, J. and Wirth,V. 2001: Diurnal winds in the Himalayan Kali Gandaki Valley, Part II: Modelling. Mon. Wea. Rev. 129: 1062-1080. 